\title{
MONITORING THE ENVIRONMENTAL CHANGES OF MARIOUT LAKE DURING THE LAST FOUR DECADES USING REMOTE SENSING AND GIS TECHNIQUES
}

Donia, Noha, S. ${ }^{(1)}$; El Kafrawy, S. B. ${ }^{(2)}$ and Mohamed, Amany, M. ${ }^{(2)}$ 1) Institute of Environmental Studies and Researches, Ain Shams University (ASU) 2) National Authority for Remote Sensing and Space Sciences (NARSS).

\begin{abstract}
The Mariout Lake is one of the most severely impacted water bodies in the Nile Delta. Multidates satellite images have been used in this study to detect the trends of environmental changes in Mariout Lake, particularly for the main two lake ecosystems; water, and aquatic vegetation during the past four decades from 1972 to 2016. A combination of LandSat-1(MSS), LandSat-5 (TM), LandSat-7 (ETM+), SPOT-1, SPOT-4, SPOT-5, RapidEye, and Sentinel-2 Satellite data was used to analyze temporal changes in the Lake ecosystem. Different image processing techniques were undertaken that performed with the ERDAS Imagine (2013) and ARCGIS (10.2.2) software such as; atmospheric correction, geometric correction, on-screen digitizing to delineate the lake boundary, the Normalized Difference Water Index (NDWI) to quantify the change in the water body area of the Lake, and change detection to ascertain the changes in water and aquatic vegetation features during last four decades interval. The results of analysis indicated that Lake lost $11.19 \mathrm{~km}^{2}$ of its overall size; NDWI indicated that change in aquatic vegetation for all basins increased by $27.68 \mathrm{~km}^{2}$, and the changes in water for all basins decreased by $38.67 \mathrm{~km}^{2}$. The change detection results showed changed area that converted into aquatic vegetation, unchanged area that still water, and lost area that no longer exists. These results that due to different anthropogenic activities such as drying and reclaiming some areas that have dangerous impacts on its quality and a subsequent deterioration in its ecological parameters.
\end{abstract}

Key Words: Atmospheric correction, NDWI, Change detection. 
J. Environ. Sci.

Institute of Environmental Studies and Research - Ain Shams University

\section{INTRODUCTION}

Remotely sensed data could use as a tool to detect, monitor and evaluate the changes in ecosystems. In recent studies, Satellite and airborne data are used to develop strategic management and change detection plans for ecosystem resources, especially for large-scale earth surface. (Donia, 2015) noted that common types of detectable change in remotely sensed data associated with the clearing of natural vegetation, increased cultivation, urban expansion, changing surface water levels, vegetation regeneration, and soil disturbances resulting from mining, landslides, and animal overgrazing. Satellite data is very suitable in inventorying the kind, quality, distribution, and condition of natural vegetation found on the range and forest lands (Ahmed et al., 2006). The key to effective environmental monitoring is the availability of different dates of imagery for the same area. Monitoring global, regional and local areas can be performed by restricting the analysis to a single sensor series or by using different satellite data. New multi-source satellites are creating data at higher spatial and temporal resolution than have been collected at any other time on earth. The selection of low cloud cover imagery with careful attention to images acquired dates in the study period is very important. Mariout Lake is a highly dynamic aquatic system that has undergone considerable physical, chemical and biological changes during last four decades. The lake has been gradually transformed from a largely marine to the eutrophic water system, due to continuous drying processes for cultivation purpose, human settlement and pollution with different kinds of water discharge into the lake. Many studies have been conducted to describe 
the ecology of the lake. However, none of the previous studies have been implemented to protect the continuous damage and restoration of Mariout Lake. In this paper, we used remote sensing and GIS techniques to measure the spatial distribution of aquatic vegetation and open water areas in Mariout Lake during the last four decades. The dataset used in this study consists of observations by LandSat-1(MSS), LandSat-5 (TM), LandSat-7 (ETM+), SPOT-1, SPOT-4, SPOT-5, RapidEye, and Sentinel-2 satellite data. The rest of the paper organized as follows. In Section 2, the study area introduced. In Section 3, the materials and methods used in this study discussed. In Section 4, experimental results reported. Finally, Section 5 gives the conclusion and recommendations of this paper.

\section{STUDY AREA}

The current Mariout Lake is a small portion of a larger lake that was known during the Roman era by Lake Mariutus. Mariout Lake is a small shallow basin located in the southwestern part of Alexandria; it is $25 \mathrm{~km}$ long and about $10 \mathrm{~km}$ width as shown in Fig (1). It is the smallest, and the most polluted lake among the northern lakes of Egypt and it is the only one that does not have a natural connection to the Mediterranean Sea. The excess water constantly discharged into the sea through El-Max Pumping Station (Abdelmoniem et al., 1987). It is now divided artificially into four basins, namely the main, the fisheries, the southern-west (SW) and Northern-west (NW) basins (Matta et al., 2007). The lake serves as a drainage basin for the adjacent cultivated lands (Ezz and Aziz, 1999); therefore, the main basin of 
the lake has been suffering from high pollution levels. Water quality was not suitable for aquaculture activities because the basin receives daily about $200,000-300,000 \mathrm{~m}^{3} /$ day of sewage and $400,000 \mathrm{~m}^{3} /$ day of agricultural waste water mixed with sewage. Also discharging about 25,000 - 35,000 $\mathrm{m}^{3} /$ day of raw sewage and some industrial waste water into the lake (Scapini, 2009; Kassim, 2005). Throughout the last four decades, the lake has subjected to man-made changes in its morphometric features as its area has reduced.

\section{MATERIALS AND METHODS}

Satellite Data: Eight satellite images used in this study. Table (1) shows the sensor type, its resolution and the date of image acquisition. Landsat (MSS, TM, ETM+, ETM), and Sentinel-2 given by Global land cover facilities (GLCF) and the United States Geological Survey (USGS) used, and the SPOT-1, SPOT-4, SPOT-5, and Rapideye images have been given by NARSS. All bands data were available, including the metadata files.

Image Processing: Image Processing is used to enhance raw images received from cameras and sensors placed on satellites. We divided this step into preprocessing and post-processing techniques. Preprocessing of image data will include atmospheric correction and geometric correction. Post-processing will include on screen digitizing, NDWI, and change detection.

Preprocessing included the following techniques:

Atmospheric correction determines true surface reflectance values and retrieve physical parameters of the Earth's surface, including surface reflectance, by eliminating effects of dust, haze, and smoke as well as the 
solar angle variations from satellite images (Hadjimitsis et al., 2010). Many atmospheric correction methods have proposed for use with multi-spectral satellite imagery (Hadjimitsis et al., 2004). This study will use FLAASH tool of ENVI (5.1) and ATCOR-2 tool of ERDAS IMAGINE (2013). The digital number (DN) values should be converted to a physical unit, using the calibration data given in the header file (metadata) of the images.

Geometric correction is one of the key issues in multi-source data integration and is one of the main processing steps prior to further evaluation of the image data - namely; fusion and analysis with data from different sources and times, overlaying with existing data sets or maps, change detection, map updating or integration into Geographic Information Systems (GIS). Raw images usually contain such significant systematic and nonsystematic (geometric) distortions such as Earth's rotation, orientation, instrument error, and variations in satellite orbits that they cannot use as a map. Therefore, in this study satellite images data were geometrically corrected as a first stage of the image processing procedure. Images rectified using a set of 12 ground control points (GCPs), and digital elevation model image with a first-order polynomial transformation to create the output images with the standard spatial resolution because the study area presents an almost flat topography and the study includes analysis of the surface water in the lake. The root mean square error (RMSE) of the transformation was not permitted to exceed \pm 0.5 pixel. Satellite images data registered to Universal Transverse Mercator coordinates zone 35, WGS 84 Datum, and resampled by the nearest neighbor interpolation method (Almeida-Filho and Shimabukuro, 2002). Image registration problem is to align one image, onto a second image 
(the reference image) by computing a transformation that is optimal in some sense; the following five elements define image registration:

1) Reference image, $I_{1}(x, y)$, that is taken to be unchanged.

2) Sensed image, $I_{2}\left(f_{x}(u, v)\right.$, that is transformed to match the reference.

3) Geometric transformation, f, that's maps spatial position in one image to the other.

4) Radiometric transformation, g, that transforms intensity values in one image to other.

5) Noise term, $\mathrm{n}(\mathrm{x}, \mathrm{y})$, that model's sensor and other imaging noise.

These definitions lead to the following relation shown in equation (1) (Moigne et al., 2011).

$$
\mathbf{I}_{1}(\mathbf{x}, \mathbf{y})=\mathbf{g}\left(\mathbf{I}_{2}\left(\mathbf{f}_{\mathbf{x}}(\mathbf{u}, \mathbf{v}), \mathbf{f}_{\mathbf{y}}(\mathbf{u}, \mathbf{v})\right)\right)+\mathbf{n}(\mathbf{x}, \mathbf{y})
$$

Post-Preprocessing included the following techniques:

On-Screen digitizing that calculated total area for each basin by using ARCMAP (10.2.2).

The Normalized Difference Water Index (NDWI) was first proposed by McFeeters in 1996 to detect surface water in wetland environments, to allow for the measurement of surface water extent (McFeeters, 1996) and it produces a single grayscale image, where water is bright. Although the index created for use with different images data, it has been successfully used with other sensor systems in applications where the measurement of the extent of open water is needed (Chowdary et al., 2008; USGS, 2016). The NDWI is calculated using Equation (2):

$$
\text { NDWI }=(\text { GREEN }- \text { NIR }) /(\text { GREEN + NIR })
$$


Where: green is the TOA green light reflectance band and NIR is the TOA near-infrared (NIR) reflectance band. (McFeeters, 1996), this index ranges from -1 to +1 with water bodies of high values $($ close to +1$)($ El-Asmar and Hereher, 2011). Values of NDWI were calculated from the Satellite images using Equation (2) in the Raster Calculator tool in the Spatial Analyst extension in ARCGIS (10.2.2), then isolate water pixels.

Change-detection technique automatically discriminates the changed and unchanged pixels of the difference image. There are three main methods of change detection: 1) Image subtraction; 2) Image ratio; 3) The change detection after classification. So, we used Image subtraction method to show the changed pixels that converted into aquatic vegetation, unchanged pixels that still water, and lost pixels that no longer exist.

\section{RESULTS}

The analyses identified the rate of environmental changes over the four decades for the lake; this was undertaken using satellite images to employ historical remotely sensed data to reveal the long-term changes in the physical characteristics of the Lake. Results revealed that the preprocessing of a remotely sensed image is vital to improve the quality and to remove the errors. Atmospheric correction parameters summarized in Table (3), and results shown in Figs $(2,3)$. The Root Mean Square Error (RMSE) of Geometric correction using ERDAS IMAGINE 2013, and the number of control points for each sensor type (SPOT-1, SPOT-4, SPOT-5, and Rapideye) shown in the table (2). On-screen digitizing found that considerable changes had taken place for overall size and each Basin of 
Mariout Lake as shown in Figs $(4,5)$. The changes in area for each basin from 1972 until 2016 are: the Main Basin decreased by $6.11 \mathrm{~km}^{2}$, the Fisheries Basin decreased by $1.14 \mathrm{~km}^{2}$, the Northwest Basin decreased by $0.66 \mathrm{~km}^{2}$, and the Southwest Basin decreased by $3.28 \mathrm{~km}^{2}$. Therefore, the major landfill area violations are clearly identified in Main, Northwest, and Southwest basin, so there are noticed all over the boundary of these basins. After applying NDWI technique on all satellite images; Fig (6) illustrates the overall NDWI Changes on Mariout Lake during 1972 to 2016 for Aquatic Vegetation and water bodies. Aquatic Vegetation (floating and submerged) occupy a substantial area of the lake and can produce misleading results of the water body area. However, the study of (El-Asmar and Hereher, 2011) reported that water indices are efficient to highlight turbid water bodies, which have Aquatic Vegetation. Fig (7) illustrates the changes in Aquatic Vegetation during the study period for each basin as follows: the Main Basin increased by $4.81 \mathrm{~km}^{2}$, the Fisheries Basin increased by $0.286 \mathrm{~km}^{2}$, the Northwest Basin increased by $1.84 \mathrm{~km}^{2}$, and the Southwest Basin increased by $20.75 \mathrm{~km}^{2}$. Fig (8) illustrates the changes in water during the study period for each basin as follows: the Main Basin decreased by $10.82 \mathrm{~km}^{2}$, the Fisheries Basin decreased by $1.38 \mathrm{~km}^{2}$; the Northwest Basin decreased by 2.5 $\mathrm{km}^{2}$, and the Southwest Basin decreased by $23.96 \mathrm{~km}^{2}$. Area size values whether water or aquatic vegetation is fluctuated in most figures due to the attention of the lake by the authorities' affiliations and amount of pollution. After the completion of NDWI for all satellite images during last four decades, the image subtraction method of change detection performed to 
calculate the changed, unchanged, and lost area. Fig (9) illustrates the using before-image (NDWI image 1972) and after-image (NDWI image 2016) to derive difference image.

\section{CONCLUSIONS AND RECOMMENDATIONS}

Remote sensing proves to be very successful in monitoring Lake Boundary, aquatic vegetation, and ecological changes along the Mariout Lake. Multidates satellite images have been used to detect the trends of environmental changes in Mariout Lake during last four decades interval, particularly for the main two lake ecosystems; water, and aquatic vegetation during the past four decades. Different image processing techniques are undertaken that performed with the ERDAS IMAGINE (2013) and ARCGIS (10.2.2) software such as atmospheric correction, geometric correction, onscreen digitizing, NDWI, and change detection technique. The results of the study indicated that Lake lost $11.19 \mathrm{~km}^{2}$ of its overall size; NDWI indicated that change in aquatic vegetation for all basins increased by $27.68 \mathrm{~km}^{2}$, and the changes in water for all basins decreased by $38.67 \mathrm{~km}^{2}$. The change detection results showed changed, unchanged, and lost area. These results that due to human activities including the discharge of sewage, industrial waste and the impact of canal and road networks have a serious impact on the lake. Image processing techniques as enhancements were applied to help the identification and discrimination features in and around the lake. The ultimate goal of this remote sensing research is to provide resource managers with a useful tool to monitor natural resources such as Coastal Lagoons and make better-informed decisions about their use and conservation. Integrating all 
available data into an easily accessible data system and improves remote sensing images potential as a tool for resource managers. There is a need for a thorough assessment of the present ecological conditions of Mariout Lake as a part of the northern nation wetlands. The authorities' affiliations must work for carrying out a comprehensive ecological survey of the Lake on regular basis, for preparation of an executive action plan for the protection, and rehabilitation of the Lake by activation of a special environmental monitoring station by the lake, this should include measures to be implemented, management of implementation, required budget, schedule, and performance measures.

\section{REFERENCES}

Abdelmoniem, M. A., El-Sharkawy, F. M., and Samaan, A. A. (1987): "Some chemical features of Lake Mariut". Bull Inst. Oceanogr. Fish. Cairo., 13(1), 201-217.

Ahmed, M. H., El-Leithy, B. M., Donia, N. S., and Arafat, S. M. (2006): "Monitoring the historical changes of Lake Manzala ecosystems during the last three decades using multidate satellite images". The First International Conference on Environmental Change of Lakes, Lagoons and Wetlands in the Southern Mediterranean Region, ECOLLAW, 4-7.

Almeida-Filho, R., and Shimabukuro, Y. E. (2002): "Digital processing of a Landsat-TM time series for mapping and monitoring degraded areas caused by independent gold miners, Roraima State, Brazilian Amazon". Remote Sensing of Environment, 79(1), 4250.

Chowdary, V.M., Chandran, R.V., Neeti, N., Bothale, R.V., Srivastava, Y.K., Ingle, P., Ramakrishnan, D., Dutta, D., Jeyaram, A., Sharma, J.R. and Singh, R. (2008): "Assessment of Surface and Sub-surface 
Waterlogged Areas in Irrigation Command Areas of Bihar State Using Remote Sensing and GIS". Agricultural Water Management, 95(7), 754-766.

Donia, N. (2015): "Lake Maryut Monitoring Using Remote Sensing". Eighteenth International Water Technology Conference, IWTC18: 230-236.

El-Asmar, H. M., and Hereher, M. E. (2011): "Change Detection of the Coastal Zone East of the Nile Delta Using Remote Sensing". Environmental Earth Sciences, 62(4), 769-777.

Ezz, A., and Aziz, A. (1999): "Benthic Fauna of Maryout Lake, Egypt". Bull. Inst. of Oceanogr. \& Fish., ARE, 25, 181-202.

Hadjimitsis, D. G., Clayton, C. R. I., and Hope, V. S. (2004): "An Assessment of the Effectiveness of Atmospheric Correction Algorithms through the Remote Sensing of Some Reservoirs". International Journal of Remote Sensing, 25(18), 3651-3674.

Hadjimitsis, D.G., Papadavid, G., Agapiou, A., Themistocleous, K., Hadjimitsis, M.G., Retalis, A., Michaelides, S., Chrysoulakis, N., Toulios, L. and Clayton, C.R.I. (2010): "Atmospheric Correction for Satellite Remotely Sensed Data Intended for Agricultural Applications: Impact on Vegetation Indices". Natural Hazards and Earth System Sciences, 10(1), 89-95.

Kassim, T. A. (2005): "Forensic Analysis and Source Partitioning of Aliphatic Hydrocarbon in Lake Maruit Aquatic Sediments". Journal of Aquatic Research,31(2), 166-181.

Le Moigne, J., Netanyahu, N. S., and Eastman, R. D. (Eds.). (2011):"Image Registration for Remote Sensing". Cambridge University Press.

Matta, C. A., Kheirallah, A. M. M., Abdelmeguid, N. E., and Abdel-Moneim, A. M. (2007): "Compositions in Oreochromis Niloticus Fish". Pakistan Journal of Biological Sciences, 10(8), 1257-1263.

McFeeters, S. K. (1996): "The Use of the Normalized Difference Water Index (NDWI) in the Delineation of Open Water Features". International Journal of Remote Sensing, 17(7), 14251432.

Scapini, F. (2009): "Sustainable Management of Mediterranean Coastal Fresh and Transitional Water Bodies: A Socio-economic and Environmental Analysis of Changes and Trends to Enhance and 
J. Environ. Sci.

Institute of Environmental Studies and Research - Ain Shams University

Sustain Stakeholder Benefits". Coastal Water Bodies Nature and Culture Conflicts in the Mediterranea, 1-5.

US Geological Survey (USGS) and US Department of the Interior (2016): NDWI, Available online

http://deltas.usgs.gov/fm/data/data_ndwi.aspx

(accessed on 23 April 2016). 
Donia, Noha, et al.

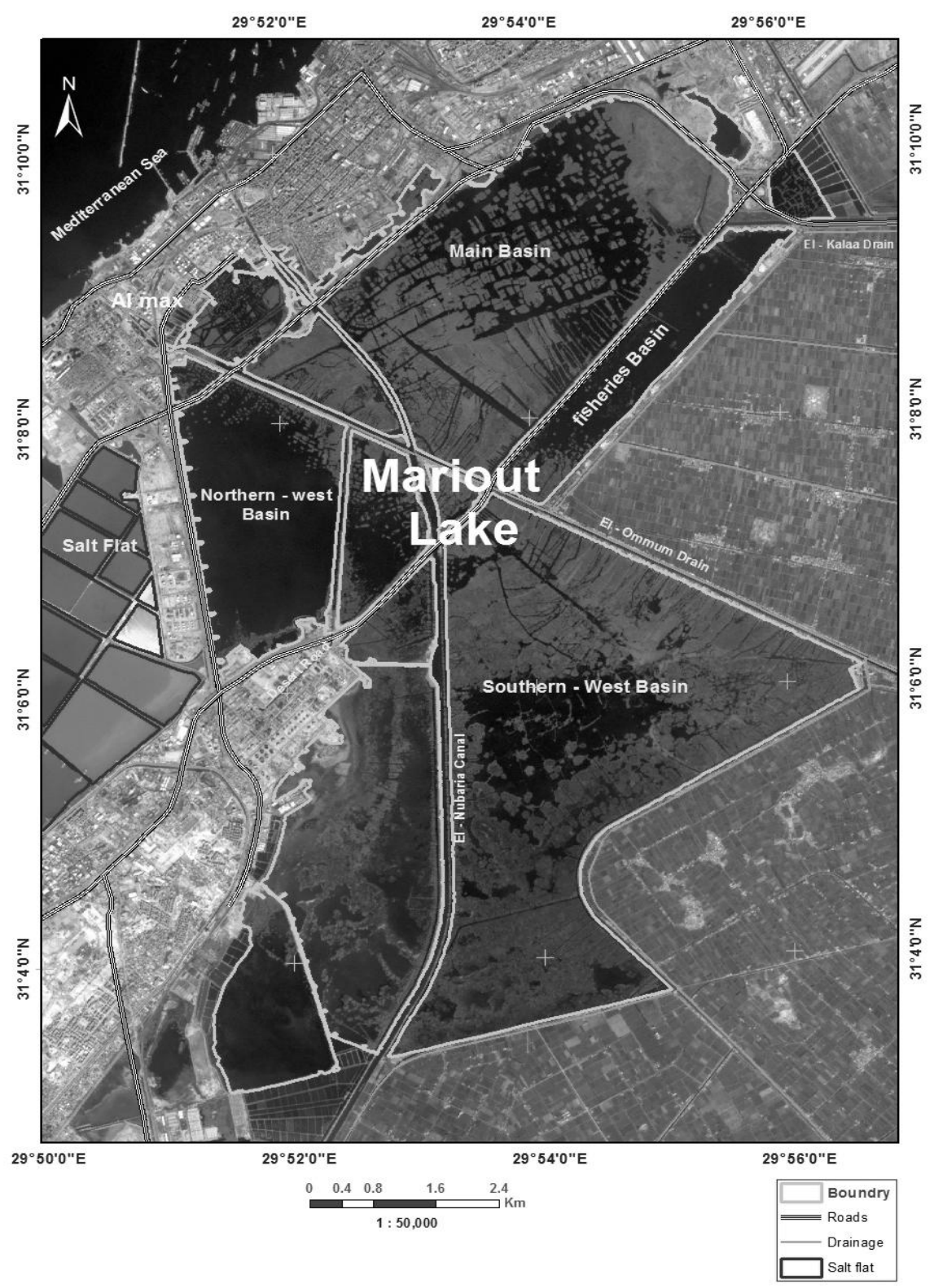

Fig (1): Rapideye (2015) showing the location of Mariout Lake 
J. Environ. Sci.

Institute of Environmental Studies and Research - Ain Shams University

Table (1): Satellite data used in the present study

\begin{tabular}{|c|c|c|c|c|}
\hline No. & Satellite Name & $\begin{array}{c}\text { No. of } \\
\text { Bands }\end{array}$ & Date & $\begin{array}{c}\text { Spatial Resolution } \\
(\mathbf{m})\end{array}$ \\
\hline $\mathbf{1}$ & LandSat 1 (MSS) & 4 & $19-09-1972$ & 57 \\
\hline $\mathbf{2}$ & LandSat 5 (TM) & 7 & $11-09-1984$ & 30 \\
\hline $\mathbf{3}$ & SPOT-1 & 3 & $23-12-2001$ & 20 \\
\hline $\mathbf{4}$ & LandSat 7 (ETM+) & 8 & $18-06-1997$ & 30 \\
\hline $\mathbf{5}$ & SPOT-4 & 4 & $19-03-2006$ & 10 \\
\hline $\mathbf{6}$ & SPOT-5 & 3 & $04-05-2009$ & 2.5 \\
\hline $\mathbf{7}$ & RapidEye & 5 & $28-01-2014$ & 5 \\
\hline $\mathbf{8}$ & Sentinel-2 & 12 & $12-02-2016$ & 20 \\
\hline
\end{tabular}

Table (2): Root Mean Square Error (RMSE) of geometric corrected images

\begin{tabular}{|l|c|c|}
\hline \multicolumn{1}{|c|}{ Satellite Name } & No. of points & RMSE \\
\hline SPOT-1 & 12 & 0.2891 \\
\hline SPOT-4 & 11 & 0.2353 \\
\hline SPOT-5 & 12 & 0.2288 \\
\hline Rapideye & 12 & 0.0002 \\
\hline
\end{tabular}

Table (3): Parameters in the atmospheric correction process

\begin{tabular}{||c|c|c|c|c|c|c|c|c||}
\hline \hline Sensor & Date & Time & $\begin{array}{c}\text { Scene } \\
\text { CenterLongitude } \\
(\mathbf{d e g})\end{array}$ & $\begin{array}{c}\text { Scene } \\
\text { CenterLatitude } \\
(\mathbf{d e g})\end{array}$ & $\begin{array}{c}\text { Solar } \\
\text { Zenith } \\
(\mathrm{deg})\end{array}$ & $\begin{array}{c}\text { Solar } \\
\text { Azimuth } \\
(\mathrm{deg})\end{array}$ & $\begin{array}{c}\text { Calibration } \\
\text { File }\end{array}$ & $\begin{array}{c}\text { Visibility } \\
\text { (km) }\end{array}$ \\
\hline \hline Landsat-1 MSS & $19-09-1972$ & $7: 58$ & 29.97 & 31.60 & 44.5 & 125.9 & mss.cal & 60 \\
\hline Landsat-5 TM & $11-09-1984$ & 8.00 & 30.29 & 30.32 & 37.5 & 128.8 & tm.cal & 30 \\
\hline Landsat-7 ETM+ & $23-12-2001$ & 8.15 & 30.36 & 30.31 & 60.7 & 148.9 & 17 etm.cal & 30 \\
\hline SPOT-1 & $18-06-1997$ & 8.87 & 30.08 & 30.95 & 17.0 & 112.1 & spot4.cal & 20 \\
\hline SPOT-4 & $19-03-2006$ & 8.75 & 29.98 & 30.95 & 43.7 & 129.9 & spot4.cal & 20 \\
\hline SPOT-5 & $04-05-2009$ & 8.74 & 29.85 & 31.07 & 22.4 & 128.1 & spot5.cal & 2.5 \\
\hline Rapideye & $28-01-2014$ & 12.77 & 29.67 & 30.99 & 61.3 & 221.9 & rapideye.cal & 5 \\
\hline Sentinal-2 & $12-02-2016$ & 12.68 & 29.67 & 31.11 & 56.8 & 223.5 & Sentinal.cal & 20 \\
\hline
\end{tabular}

*Model for solar region is maritime

102 

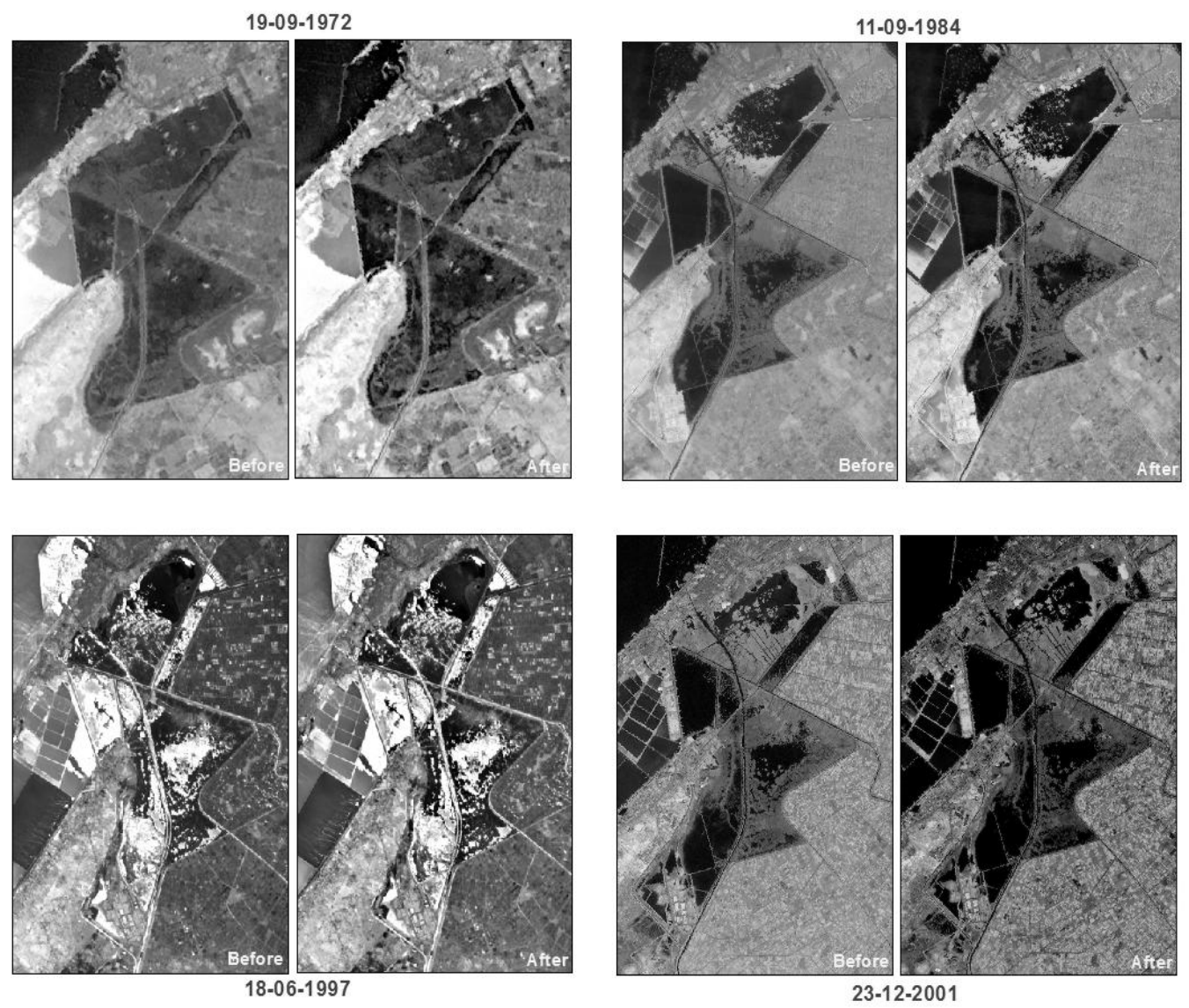

Fig (2): Atmospheric correction of satellite images; before and after atmospheric correction for each date 
J. Environ. Sci.

Institute of Environmental Studies and Research - Ain Shams University
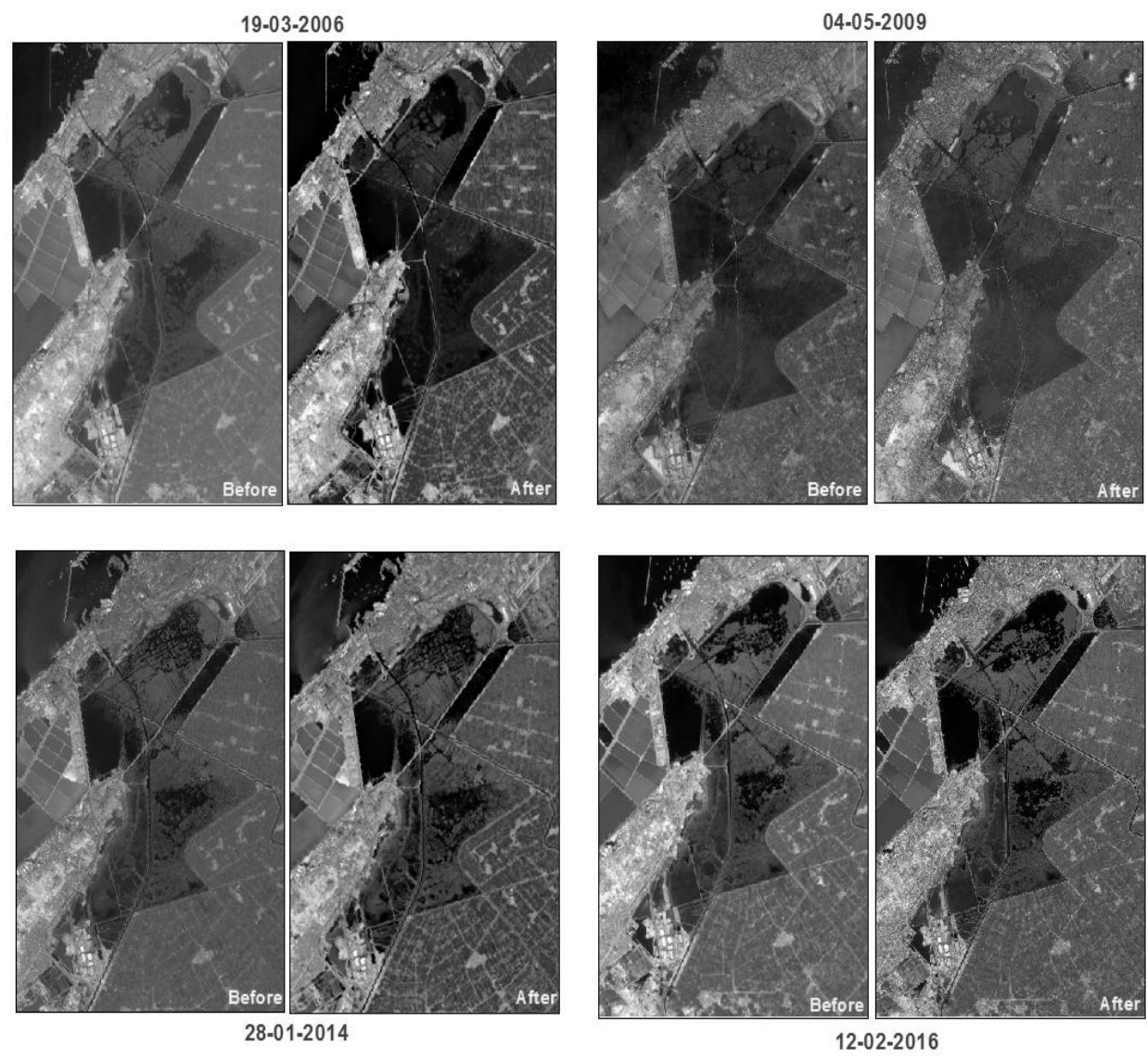

Fig (3): Atmospheric correction of satellite images; before and after atmospheric correction for each date 


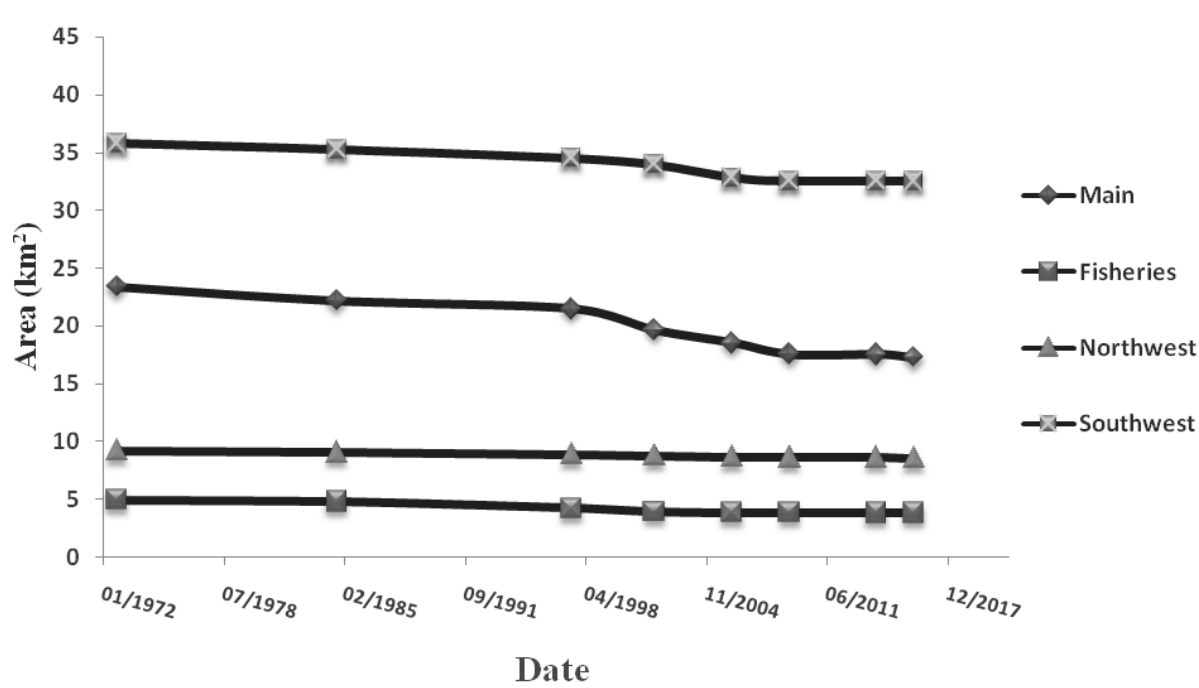

Fig (4): Changes in each basin of Mariout Lake during 1972 to 2016

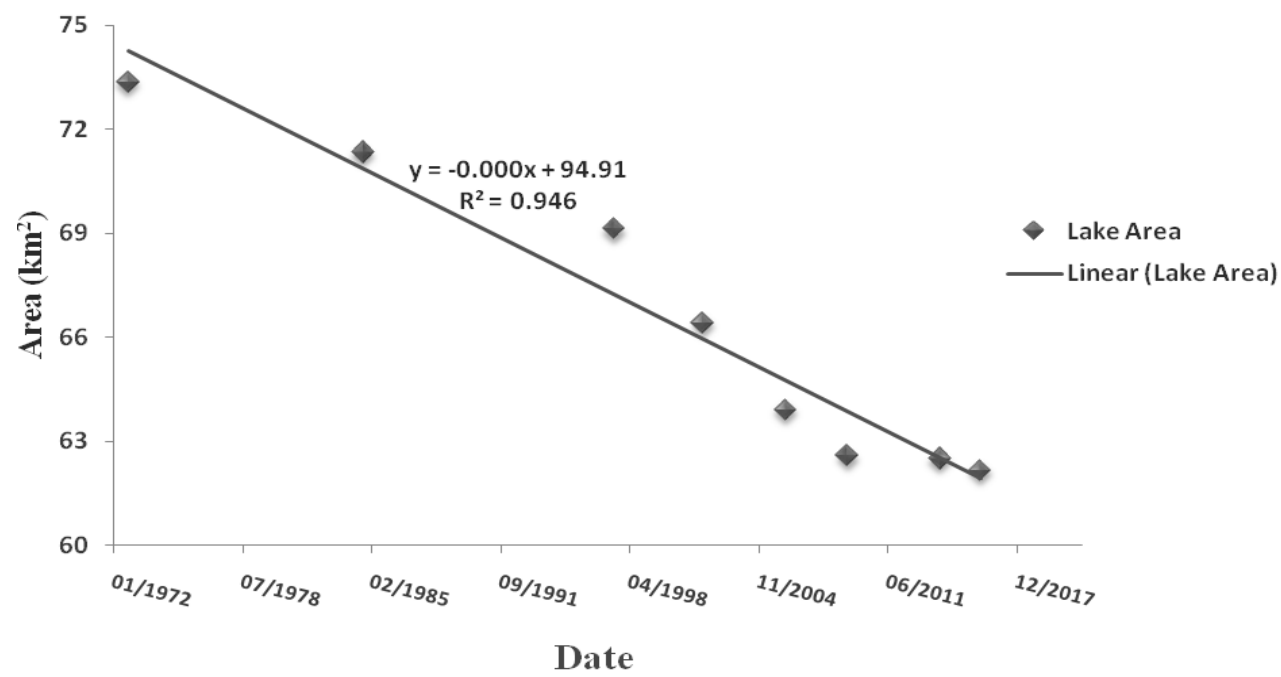

Fig (5): Overall changes of Mariout Lake during 1972 to 2016 


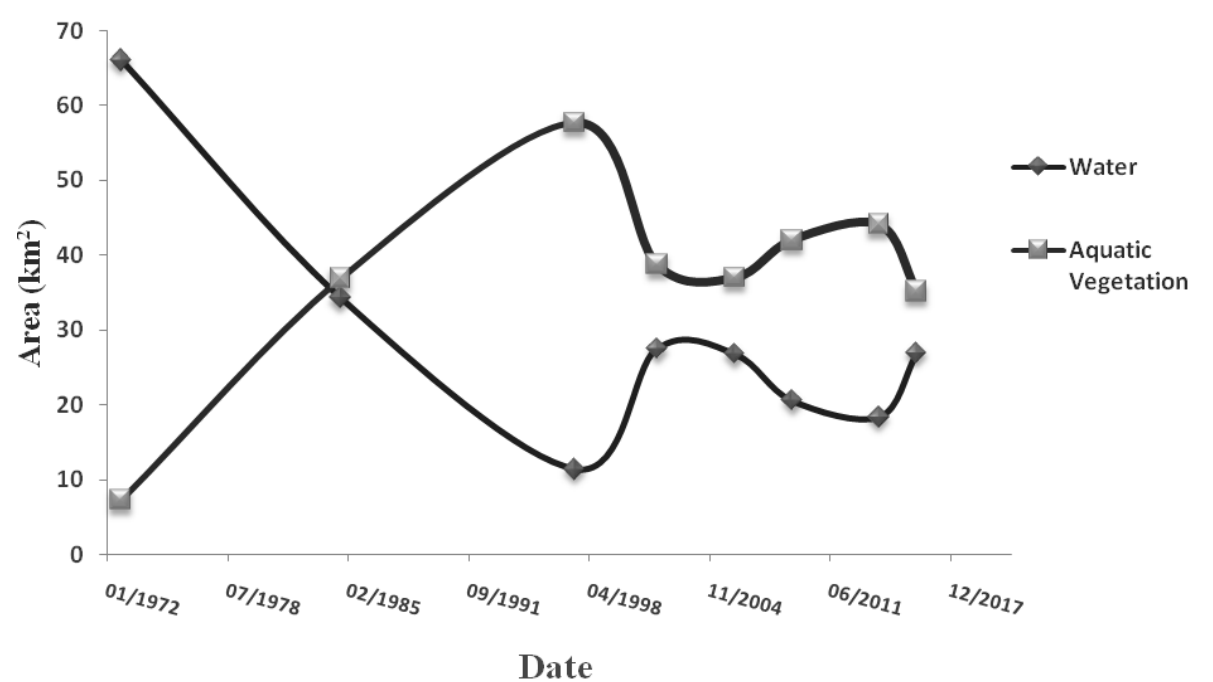

Fig (6): NDWI Changes of Mariout Lake during 1972 to 2016

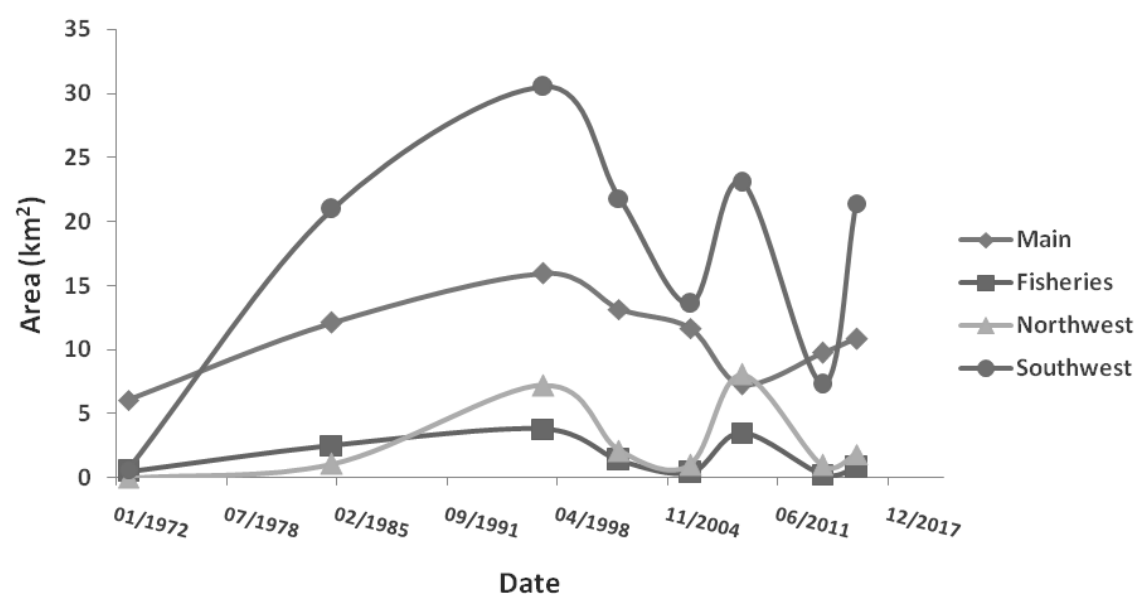

Fig (7): Aquatic vegetation Changes in basins of Mariout Lake during 1972 to 2016 


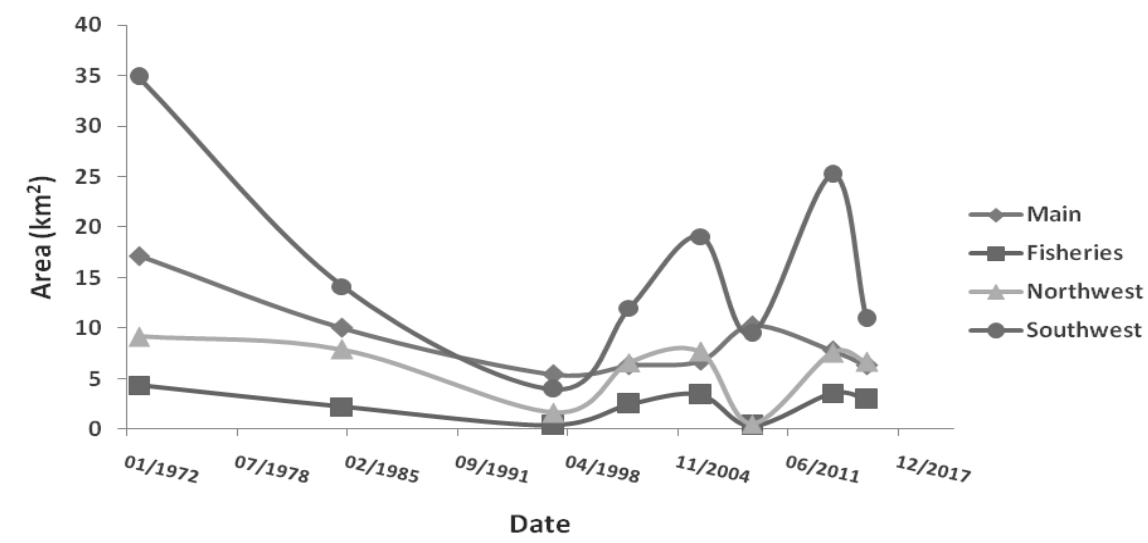

Fig (8): Water Changes in basins of Mariout Lake during 1972 to 2016
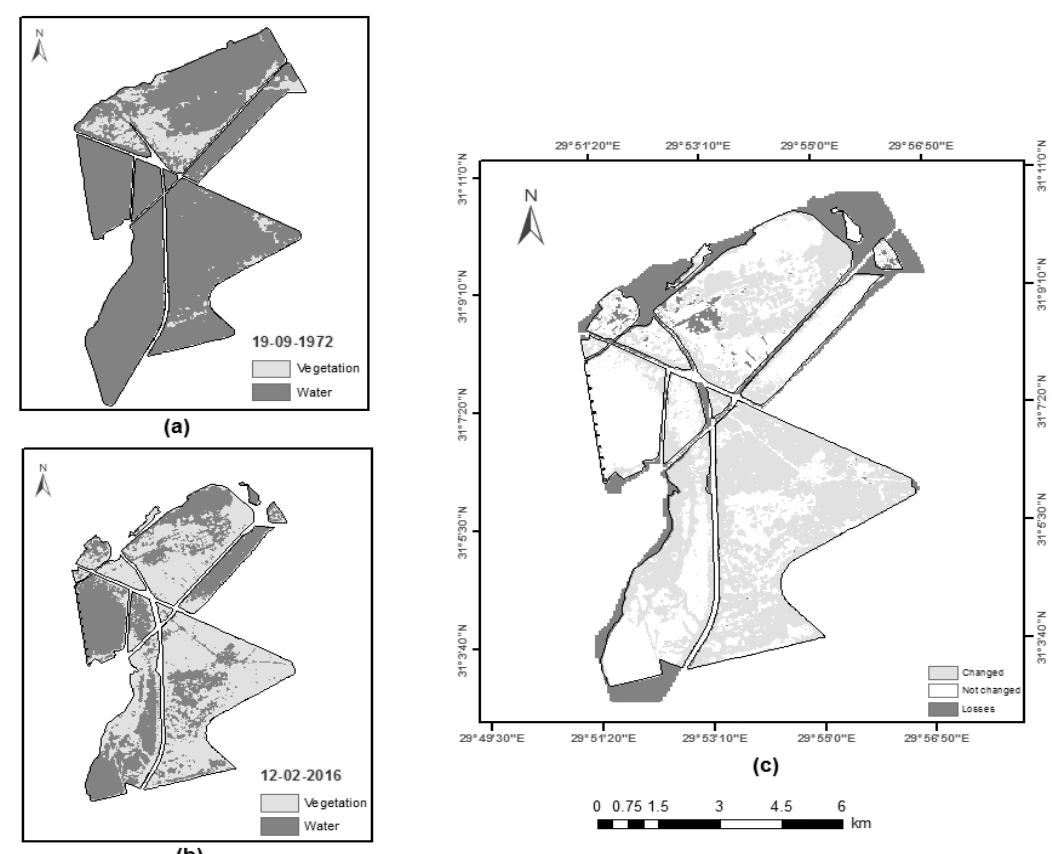

(c)

(b)

Fig (9): Change detection method a) before (1972); b) after (2016); c)

Change detection map (difference image) 


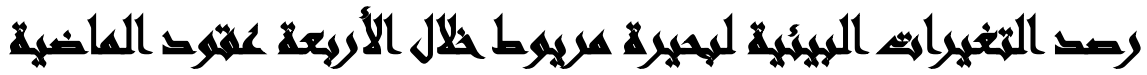

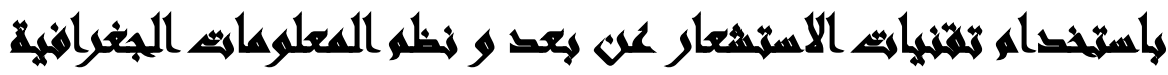

\section{$[\bullet]$}

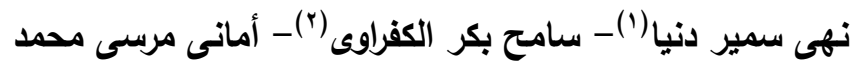

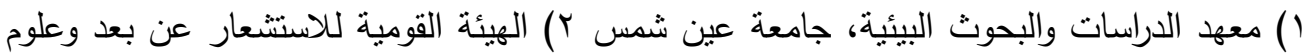

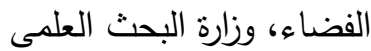

\section{llition}

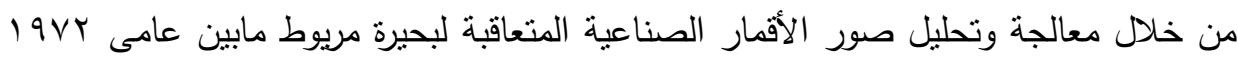

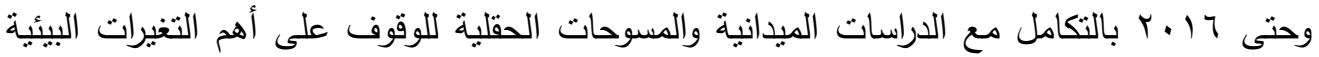
الحادثة بالبحيرة وخاصة التغييرات الحادثة فى كل من مساحتى المسطح المائى والنباتات الماتئي المائية

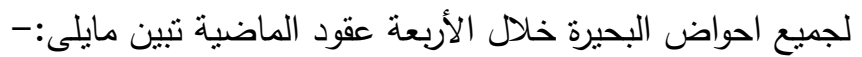

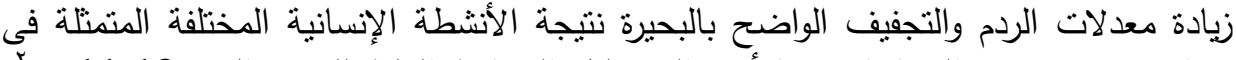

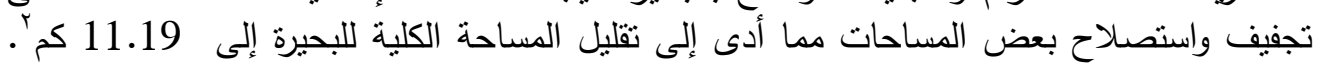

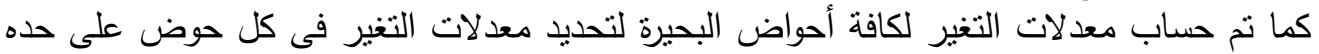

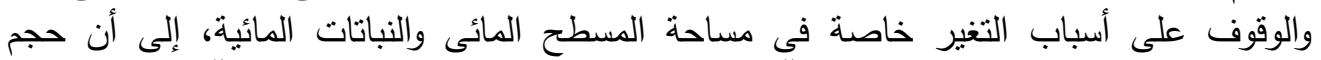

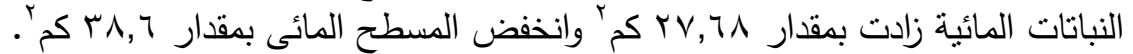

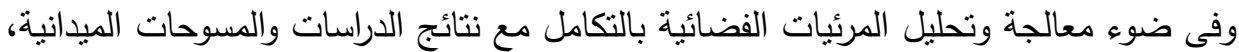

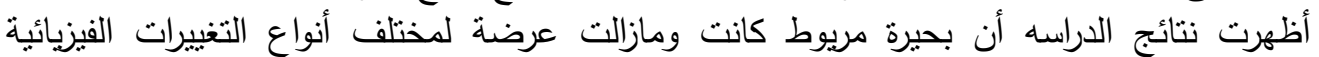

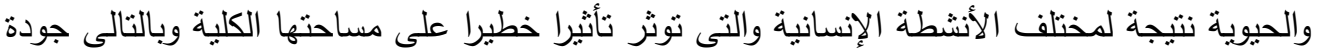
ونوعية مياهها والتأثير السلبى المستقبلى على خواصها البيئية. 